\title{
Effects of Organic Mulches on the Soil Temperature, Humidity and $\mathrm{CO}_{2}$ Emissions
}

\author{
Alicia Pou ${ }^{1 *}$, Andreu Mairata ${ }^{1}$, Estíbaliz Rodrigo ${ }^{1}$, David Labarga ${ }^{1}$, Enrique García Escudero ${ }^{1}$, Joaquín Huete ${ }^{2}$ \\ and José María Martínez Vidaurre ${ }^{1}$
}

${ }^{1}$ ICVV, Instituto de Ciencias de la Vid y del Vino (CSIC), Universidad de La Rioja, Gobierno de La Rioja), Spain

${ }^{2}$ Agro-climatic Information Service of La Rioja (SIAR), Gobierno de La Rioja, Spain

Submission: December 09, 2021; Published: December 20, 2021

*Corresponding author: Alicia Pou, Finca La Grajera, Carretera Burgos, km 6, 26007 Logroño (La Rioja), Spain

Abstract

A large portion of the world wine production is located in regions suffering - or expected to suffer - from desertification. These agricultural soils, in addition to being highly unstructured, have very low levels of organic matter $(<1 \%)$. This is aggravated by an abusive tillage of the plots, which implies that the maintenance of these soils depends entirely on the addition of chemical products such as fertilizers and herbicides. This situation, in turn, leads to physiological imbalances in the vine that result in deficiencies in the quality of the grape.

In viticulture, the development of regenerative techniques to improve soil quality is aimed at benefiting producers, and specifically at improving the productivity, sustainability and biodiversity of their soils, as well as adapting their production systems to the new climate change scenarios (response to abiotic stresses - extreme temperature, water stress -). Organic mulch is an effective method to manipulate the crop-growing microclimate increasing crop yield by controlling soil temperature and retaining soil moisture by reducing soil evaporation. Moreover, carbon dioxide $\left(\mathrm{CO}_{2}\right)$ emissions are also mitigated by this practice. The effectiveness of different organic mulching materials applied within the row of a vineyard was evaluated in a Tempranillo vineyard located in La Rioja (Spain). Organic mulches (straw mulch, SM; grapevine pruning debris, GPD and spent mushroom compost, SMC) were compared with two traditional bare soil management techniques (one based on the use of herbicides to avoid weed incidence and one based on the use of the tillage inter-row).

Keywords: Mulching, bare soil; Soil moisture; Soil temperature, $\mathrm{CO}_{2}$ respiration

Abbreviations: SM: Straw Mulch; GPD: Grapevine Pruning Debris; SMC: Spent Mushroom Compost

\section{Introduction}

The traditional cultivation of the vine all around the world has been reconverted and more winemakers have decided to return to the origins, taking care of their vines as their predecessors, without adding additives or pesticides and promoting an ecological agriculture. Ecological production considers multiple techniques of soil management, crops and the environment, which should be considered by the producers.

The addition of an organic cover, unlike a vegetal cover, widely used in viticulture, allows to keep the soil free of weeds and to improve humidity. Among its many advantages, these soil mulching management techniques can reduce evaporation and erosion
$[1,2]$, isolate the soil from extreme temperatures [3], reduce weed infestation [4], increase the availability of nutrients and organic matter [5] and thereby may lead to increases in vine yield, vine water use efficiency (WUE) and vine nitrogen use efficiency (NUE), increase the biological activity of the soil [6], and favours the good sanitary status of the plants [7].

Concretely for grapevine cultivation, which takes place mostly in semi-arid areas all around the world [8], high water requirements are necessary to complete the growth cycle of grapevines, which coincides with the driest months [9]. Moreover, evaporative demand is expected to increase as a consequence of increased global air temperature $[10,11]$. 
Mulching is also an interesting and promising management practice to consider when accounting for carbon emissions and storage capacities. A recent meta-analysis based on data from 61 peer-reviewed publications showed that on average, straw mulch increased the emissions of $\mathrm{N}_{2} \mathrm{O}$ and $\mathrm{CO}_{2}$ by $24.7 \%$ and $4.7 \%$ respectively, while significantly promote $\mathrm{CH}_{4}$ uptake, by $22.6 \%$ compared with that of no-mulching [12]. However, the impact of soil mulching on crop yields and greenhouse gas emissions was also affected by temperature, water input amount, cultivation practice and nitrogen application rate. In this sense, decreases $[13,14]$ or no changes $[15,16]$ in soil greenhouse gas emissions by straw mulch were also observed under some cropping systems, soil types, and nitrogen fertilizer levels.

It is imperative to know the processes that control soil environments under various mulching conditions and the effects of mulching materials on crop yield, productivity and water use efficiency. In this context, the developed research aimed at studying the effects of different mulches on thermal fluctuations and humidity in the soil as well as their role in the $\mathrm{CO}_{2}$ uptake.

The study site was located in the North-Eastern Spain on a soil defined as a typical Haplocalcids soil according to the base for Soil Resource [17]. Two traditional management techniques (one based on the application of herbicides, and another based on the row cultivation) and three organic mulches (SMC, from spent mushroom compost, which is composed of straw, poultry manure and urea; S, straw and GPD, from shredded grape pruning remains from previous years) have been implemented for 4 years as cover layers in the vine cultivation.

On the one side, we measured volumetric water content (WVC) and soil temperature at different depths (5, 15 and $25 \mathrm{~cm})$. For this, several Drill \& Drop probes (Sentek, Stepney, Australia) equipped with 3 sensors have been placed. Moreover, climatic data on radiation and precipitation have been obtained from the La Rioja Agroclimatic Information Service station located in Aldeanueva de Ebro. On the other side, we measured soil respiration with a portable EGM-4 (PP Systems) equipment which directly measures $\mathrm{CO}_{2}$ concentrations emitted by the soil applied to the mulch cover or bare soil.

Mulching coverages favourably influenced the soil water retention throughout all the grapevine vegetative cycle as compared with bare soils, retaining up to $25 \%$ more water as compared to traditional treatments (Figure 1). However, the soilmoisture variation was not the same under different mulching materials, being the straw mulch (SM) the one that retained more water in the months of higher evaporative demand, compared with GPD based-cover and SMC. The changes of soil moisture in the upper surface layer $(0-10 \mathrm{~cm})$ were highly dynamic, probably due to water vapour fluxes across the soil-atmospheric interface.

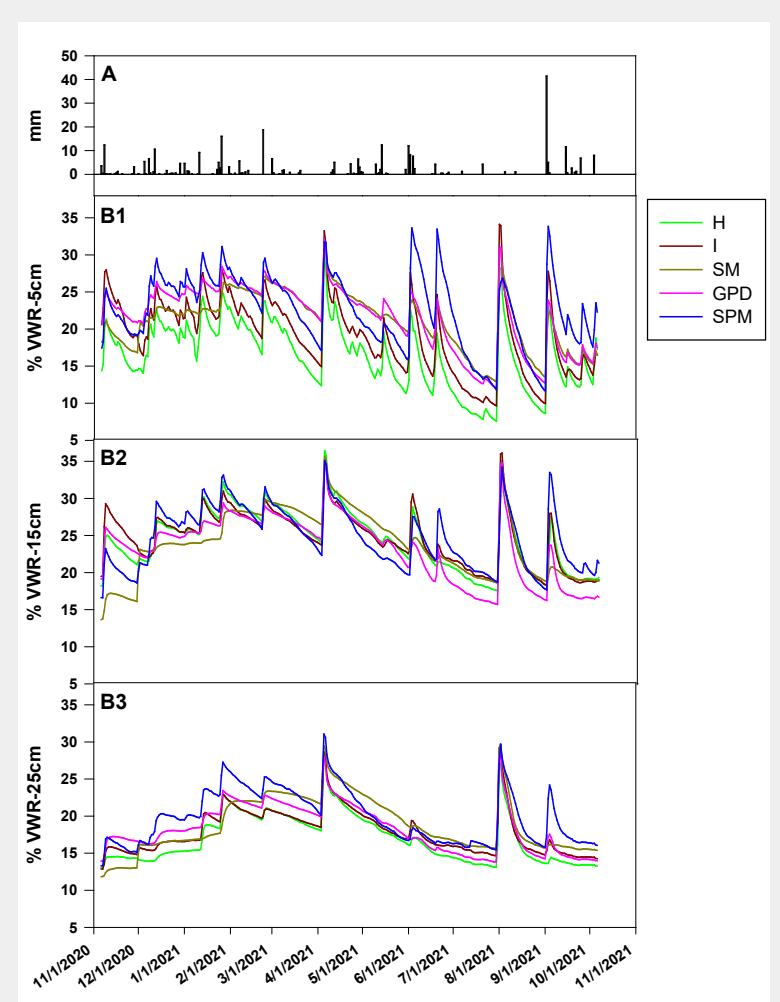

Figure 1: Daily precipitation (A) and soil volumetric water content variation under different depths: $5 \mathrm{~cm}(B 1), 15 \mathrm{~cm}$ (B2) and 25cm (B3) for different management soil strategies during the 2021 grapevine cycle season. H: Herbicide; I: Inter-row Cultivation; SM: Straw Mulch; GPD: Grapevine Pruning Debris; SMC: Spent Mushroom Compost. 
A similar trend occurred with mean soil temperature (Figure 2). Organic mulches altered soil temperature in comparison with bare soil by reducing soil temperature in summer and raising it in winter. Moreover, the same buffering effect for the temperature on the covered soil also remains in the deeper layers.

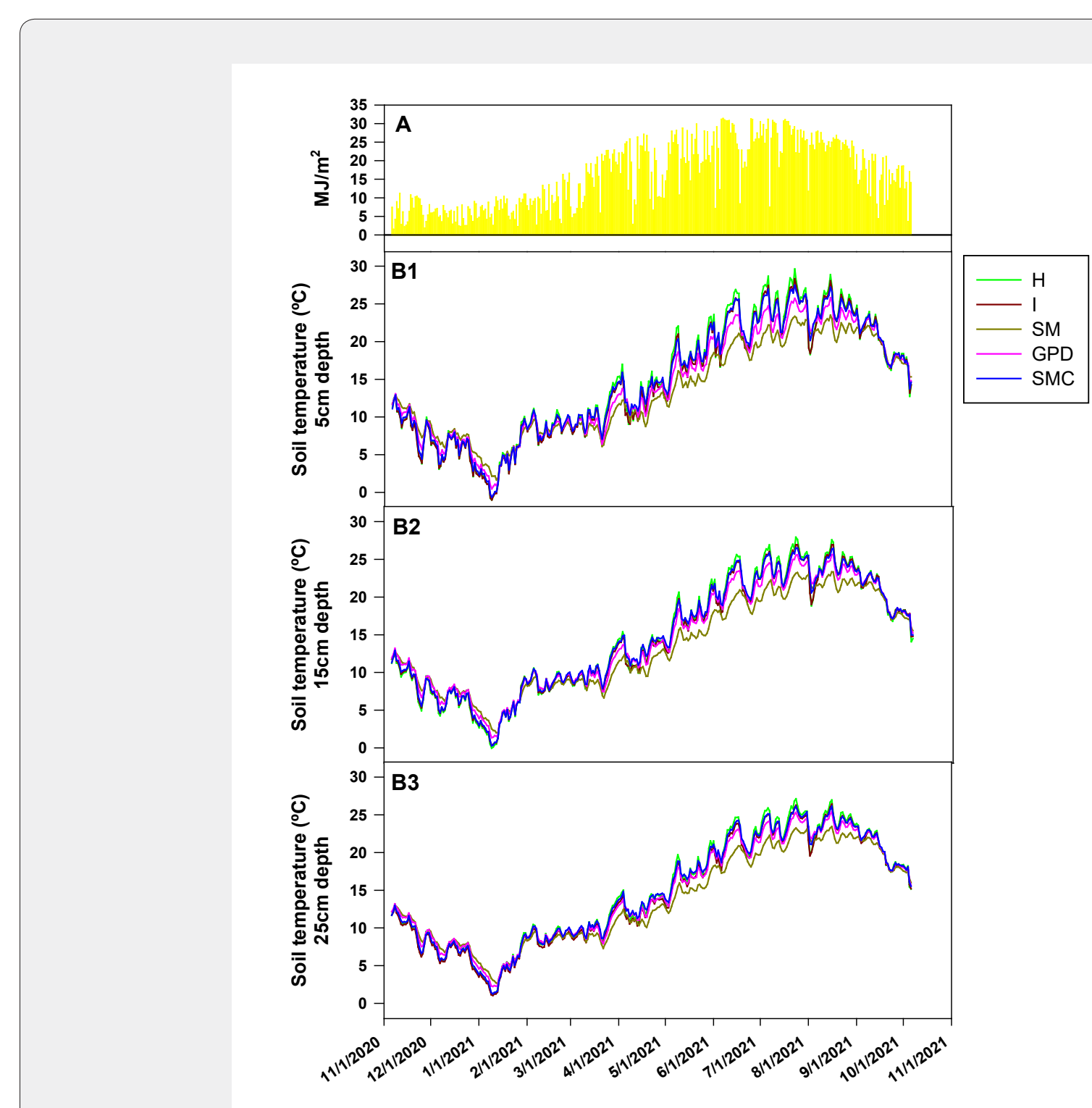

Figure 2: Solar radiation (A) and daily variation of the soil temperature under different depths: $5 \mathrm{~cm}(B 1), 15 \mathrm{~cm}(B 2)$ and $25 \mathrm{~cm}(B 3)$ for different management soil strategies during the 2021 grapevine cycle season. H: Herbicide; I: Inter-row Cultivation; SM: Straw Mulch; GPD: Grapevine Pruning Debris; SMC: Spent Mushroom Compost.

In this study, various mulching materials were applied to the soil surface, aiming to study their impact on the soil respiration and alterations on the carbon dioxide $\left(\mathrm{CO}_{2}\right)$ emission pattern.

We observed that the three studied mulches influenced the soil respiration mainly through changing the soil surface properties, which affected the soil temperature, moisture, as well as soil gas concentration. Concretely, seasonal average $\mathrm{CO}_{2}$ fluxes (from grapevine flowering up to maturity) were lower for mulched than unmulched treatments, except for SMC (Figure 3). $\mathrm{CO}_{2}$ emissions within the different mulches were ranking as SMC > $\mathrm{SM}=\mathrm{GPD}$. These results might be induced by the soil biochemical processes which control $\mathrm{CO}_{2}$ production and consumption and affects microorganism and root activity $[18,19]$. So, in this study, GPD and SM improved soil fertility and increased crop yield (data not shown) and partially offset the increase of $\mathrm{CO}_{2}$ emissions. SMC similarly increased crop yield but at expenses of increase the risk of soil $\mathrm{CO}_{2}$ emissions. 


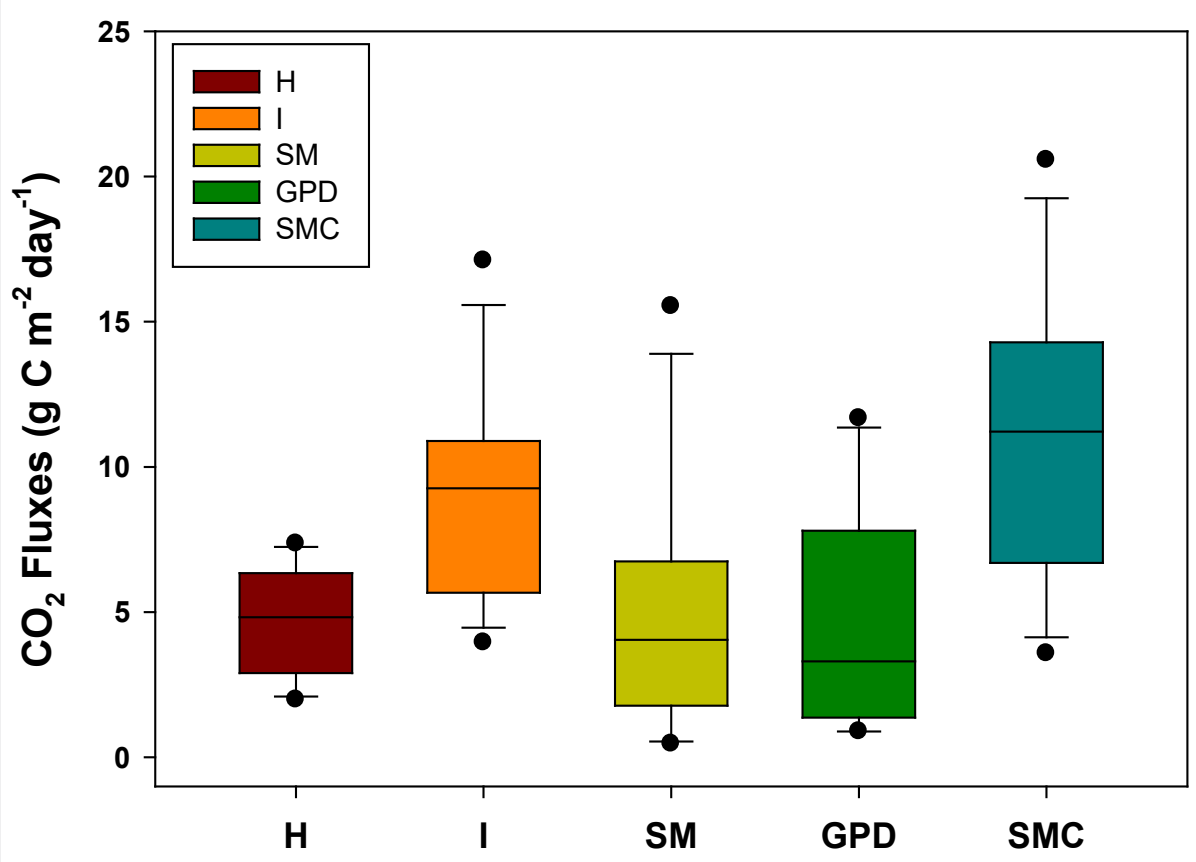

Figure 3: Seasonal variations (flowering up to maturity) of the $\mathrm{CO}_{2}$ emissions under the various treatments. H: Herbicide; I: Interrow Cultivation; SM: Straw Mulch; GPD: Grapevine Pruning Debris; SMC: Spent Mushroom Compost. Vertical bars denote the standard error of the mean $(n=15)$.

\section{Conclusion}

To conclude, we could see that organic mulch had a positive impact on soil-moisture storage and soil temperature, thus favouring crop growth and grape yields and that the extent of these effects depends on the type of mulching materials. These changes led to higher rates of $\mathrm{CO}_{2}$ retention in GPD and SM treatments as compared with bare soils, whereas SMC significantly enhance soil $\mathrm{CO}_{2}$ emissions.

\section{Acknowledgement}

This study was jointly supported by the FEDER Funds and the RTI2018-095748-R-I00 Project (Ministerio de Ciencia, Innovación y Universidades).

\section{References}

1. Pinamonti F (1998) Compost mulch effects on soil fertility, nutritional status and performance of grapevine. Nutrient Cycling in Agroecosystems 51: 239-248.

2. Varga P, Májer J (2004) The use of organic wastes for soil-covering of vineyards. Acta Horticulturae 652: 191-197.

3. Dahiya, Ingwersen J, Streck T (2007) The effect of mulching and tillage on the water and temperature regimes of a loess soil: experimental findings and modelling. Soil Tillage Research 96: 52-63.

4. Frederikson L, Skinkis PA, Peachey E (2011) Cover crop and floor management affect weed coverage and density in an establishing Oregon vineyard. Horticulture Technology 21(2): 208-216.

5. Jacometti MA, Wratten SD, Walter M (2007) Management of understorey to reduce the primary inoculum of Botrytis cinerea: Enhancing ecosystem services in vineyards. Biological Control 40: 5764.

6. Thomson LJ, Hoffmann AA (2007) Effects of ground cover (straw and compost) on the abundance of natural enemies and soil macro invertebrates in vineyards. Agricultural Forest Entomology 9(3): 173179.

7. Mundy DC, Agnew RH (2002) Effects of mulching with vineyard and winery waste on soil fungi and Botrytis bunch rot in Marlborough vineyards. New Zealand Plant Protection 55: 135-138.

8. Flexas J, Galmés J, Gallé A, Gulías J, Pou A, et al. (2010) Improving water use efficiency in grapevines: potential physiological targets for biotechnological improvement. Australian Journal of Grape and Wine Research 161: 106-121.

9. Williams LE, Ayars JE (2005) Grapevine water use and the crop coefficient are linear functions of the shaded area measured beneath the canopy. Agricultural and Forest Meteorology 132(3-4): 201-211.

10. IPCC: Summary for Policymakers. In: climate change (2018) Global Warming of $1.5^{\circ} \mathrm{C}$ : An IPCC special report on the impacts of global warming of $1.5^{\circ} \mathrm{C}$ above pre-industrial levels and related global greenhouse gas emission pathways, in the context of strengthening the global response to the threat of climate change, sustainable development, and efforts to eradicate poverty. Intergovernmental panel on climate change. 
11. Vicente Serrano SM, Lopez Moreno JI, Beguería S, Lorenzo Lacruz J, Sanchez Lorenzo A, et al. (2014) Evidence of increasing drought severity caused by temperature rise in Southern Europe. Environment Research Letter 9(4): 044001.

12. Wang H, Zheng J, Fan J, Zhang F, Huang C (2021) Grain yield and greenhouse gas emissions from maize and wheat fields under plastic film and straw mulching: A meta-analysis. Field Crops Research 270: 108210

13. Zou J, Huang Y, Jiang J, Zheng X, Sass RL (2005) A 3-year field measurement of methane and nitrous oxide emissions from rice paddies in China: effects of water regime, crop residue, and fertilizer application. Global Biogeochem Cy 19: 1-9.

14. Gou Z, Yin W, Chai Q (2021) Straw and residual film management enhances crop yield and weakens $\mathrm{CO}_{2}$ emissions in wheat-maize intercropping system. Scientific Reports 11(14077).

15. Shan J, Yan X (2013) Effects of crop residue returning on nitrous oxide emissions in agricultural soils. Atmospheric Environment 71: 170-175.
16. Zhang J, Hang X, Lamine SM, Jiang Y, Afreh D, et al. (2017) Interactive effects of straw incorporation and tillage on crop yield and greenhouse gas emissions in double rice cropping system. Agriculture, Ecosystems and Environment 250: 37-43.

17. Soil Survey Staff (2006) Keys to Soil Taxonomy (10th Edition). USDANatural 736 Resources Conservation Service, Washington DC, USA.

18. Maier CA, Kress LW (2000) Soil $\mathrm{CO}_{2}$ evolution and root respiration in 11-year-old loblolly pine (Pinus taeda) plantations as affected by moisture and nutrient availability. Canadian Journal of Forest Research 30(3): 347-359.

19. Tiquia SM, Lloyd J, Herms DA, Hoitink HAJ, Michel FC (2002) Effects of mulching and fertilization on soil nutrients, microbial activity and rhizosphere bacterial community structure determined by analysis of TRFLPs of PCR-amplified 16S rRNA genes. Applied Soil Ecology 21: 3148. 